\title{
FACULTY ACCOUNTABILITY AND FACULTY WORKLOAD: A Preliminary Cost Analysis of Their Relationship As Revealed by PhD Productivity
}

\author{
Robert T. Blackburn, Professor of Higher Education, Center for the Study \\ of Higher Education, The University of Michigan, Ann Arbor, Michigan
}

Keith W. Trowbridge, Director, Planning and Institutional Analysis, Florida international University, Miami, Florida

General concerns for faculty accountability are examined in the context of faculty workload and costs. Graduating a PhD student is used as the unit for analysis. The unit is compared to instructional productivity. The data came from a 10-year interval at a major graduate university. Six liberal arts departments with a 225 -member faculty provide the $\mathrm{PhD}$ output and workload information. Work equivalents are determined from institutional and faculty self-reports. Graduating $\mathrm{a} \mathrm{PhD}$ is found to be equivalent to onethird of a full workload. Implications are given for comparisons between programs within a university and between types of institutions in the larger system of higher education. Concerns also emerge for improved personnel practices with respect to faculty work assignments.

Two matters press on higher education today with increasing intensity. They are faculty accountability and the need for criteria for allocating limited resources among competing and differing programs and institutions. Questions being asked are: What does a program cost? Are faculty doing their jobs? Is faculty output commensurate with the dollars being expended? ${ }^{1}$ Important questions like these need answers. They require close analysis of interrelated issues.

This preliminary analysis concentrates on faculty and institutional production of PhD students. Narrowing the scope produces a sharper picture and magnifies

\footnotetext{
1 "Producer," "output," and the like are crude items, especially when human beings are the subjects. Using the argot of job analysis-as this research requires-makes us sound compassionless. We sincerely believe the opposite to be the case. In fact, it was the deeply personal nature of the PhD sponsor-candidate relationship which motivated this inquiry.
} 
the extremes of high and low cost. At the same time, it illuminates the problems of private as well as public higher education, of undergraduate as well as graduate programs. Additionally, production of a $\mathrm{PhD}$ is a precise unit which links the work effort of an individual faculty member, the candidate's sponsor, to a specific output. Comparative cost analyses can be extended to other processes by the method developed here.

\section{BACKGROUND}

\section{Cost}

To begin with, a long standing rule-of-thumb cost formula now receives empirical corroboration. The first two years of college, the last two plus the first year of graudate work (including the masters), and doctoral level graduate work are in a cost ratio of 1:2:4 (Hansen and Sandler, 1967; Carnegie, 1970, p. 21). Said another way, doctoral education cost twice upper division and beginning graduate; it is four times as expensive as the first two years of college.

Before examining the consequences of these expense ratios in more detail, it is essential to keep firmly in view that no value judgment is being made on any level of education due to cost differential. Goodness or badness, better or worse are not involved. Despite the country's momentary imbalance of trained people and unemployment, society is always going to need a wide range of highly educated persons and complex equipment. It is not that a doctor is more important than a medical technologist, or that an electron microscope is more vital than a pair of glasses. What is involved is the simple fact that it costs more to produce some kinds of trained people and things than it does others. ${ }^{2}$

It follows that those institutions that society has designated to produce the more costly trained personnel require funds in proportion to the ratios indicated previously. Legislators who deal with the full spectrum of higher education-community colleges, four-year colleges, emerging universities with some graduate programs, and mature universities with a wide mix of doctoral programs-know costs are far from equal across types. Similarly, private college and university Boards who are considering adding or deleting programs recognize the differential costs and savings of programs requiring different degrees of training. The

\footnotetext{
${ }^{2}$ Additionally, future income is not always in proportion to the expense of the education involved. It is true that the phsyician's education is extraordinarily expensive and that his income is the highest of all professional people. But a lawyer, whose earnings rank second, requires as education that costs much less, as does that of an MBA or an engineer. On the other hand, a minister with a DTh or a professor with a PhD spends even greater sums and defers income for longer a period of time than does any of those mentioned above. Furthermore, the professor's income is far below that of the professionals previously mentioned, as well as below the income of chiropractors, airplane pilots, athletes, half of the 48 groups in the U.S. Census Bureau (1964) comparative studies of professional incomes.
} 
matter of how costs relate to faculty productivity, then, depends upon faculty workload, the time required for various kinds of outputs.

\section{Faculty Workload}

The literature on faculty work effort both rewards and frustrates the needed analysis. Too often the latter is the case.

An examination of 60 articles, books, pamphlets, and conference reports dealing directly with faculty workload, and 74 studies related indirectly to faculty workload (role, identity, ethics, training, and general faculty characteristics) yielded considerable subjective opinion on the diversity and demanding nature of faculty workload; however, statistical information was lacking. Few academicians have approached the topic through carefully planned analyses of faculty workload.

In a study of faculty workload more than 50 years ago, Koos made the statement:

Tradition, sentiment, rule of thumb and temporizing compromise, these have been and unfortunately still are the dominant method used in educational administration (Koos, 1919).

Ten years later Reeves and Russell, in a study of instructional loads, stated:

The evaluation of faculty load is an extremely difficult problem. Teaching duties and other professional duties vary tremendously from institution to institution and from individual to individual within a given institution. In fact, the factors involved in determining total faculty load are so numerous and so varied as almost to preclude precise determination by any mechanical method. No thoroughly scientific method of measuring faculty load is now available. Existing measures are unsatisfactory and incomplete. The answers are not yet in. Yet, as a practical necessity, some method of measuring and adjusting faculty load-even though only approximate-must be employed (Reeves and Russell, 1929).

Seventeen years later Russell again summarized the state of this art:

Discouragingly little progress has been made in recent years in improving the technique of evaluating faculty service loads. Research is needed to point the way to better procedures of a sort that will be practical in internal administration of colleges and universities (Russell, 1946).

The need for defining faculty workload in a meaningful way has long been given lip service by educators. A conference of the American Council on Education in 1960 , dealing specifically with faculty workload, concluded:

The need for a generally accepted definition of faculty workload has long been recognized by such national agencies as the American Association of Collegiate Registrars and Admissions Officers, the American Council on Education, and the U.S. Office of Education. ... Unless an educational group takes the initiative in working out definitions, other non-educational agencies will do so (Bunnell, 1960, p. 63).

Despite the need for faculty workload studies, discouragingly little progress has been made. Bunnell (1960), Stecklein (1961), and Richardson (1967), who 
have conducted relatively comprehensive work in this area, do not give even passing comment to the faculty effort involved in dissertation advising. No doubt reasons for nonactivity reside partly outside offices of institutional research. Faculty resist time studies of their professional role. Their reasons are many. Threats to their autonomy exist. Also, Taylor's analyses were anything but humane. Besides, there is strong personal factor that can never be ignored. As a master Dean remarked sometime ago:

There is something inherently shocking to any [professor] in the idea that his [work], which is the outcome of his whole training, his whole philosophy of life, the accidents of his departmental and school environment, of his assigned task in a college system, of his selection of pupils, his state of health, his personal relations with colleagues and administration-that the unique product of all these factors should be represented by a place on a scale or by a number (Guthrie, 1949, p. 109).

On the quantitative side, however, a group of studies report the total number of hours faculty work in a typical week. McElhaney (1959), Gerstl (1959), Stecklein (1961), WICHE (1961), French, et al. (1965), Clark (1968), Kilpatrick (1969), University of Minnesota (1970), University of Michigan (1970), and Keene (1971), each find that faculty work between 53 and 60 hours per week, with a high preponderance at 55-57 hours. The small interval gives credence to the reported figures. In addition, Stecklein (1961) and French et al. (1965) have independent corroborations of the work hours faculty reported. Hence, 55 hours per week is a highly reliable number. It will be used below with full confidence.

What follows is an intensive investigation designed to penetrate the umbra which heretofore has shaded the data needed for a full analysis.

\section{THE SETTING}

The years from 1960 to 1970 at a large, midwestern university, known nationally for its high doctoral output, provide the setting for the study. Although doctoral output continues to rise, the university no longer is expanding. Six liberal arts departments were selected, two each from the humanities, the natural sciences, and the social sciences. (The departments follow those used in the Parson and Platt (1968) study.)

Briefly, a $69 \%$ response from a 225 ranked faculty (i.e., assistant, associate, and full professors) gave opinions, attitudes, and estimated work effort with respect to the $\mathrm{PhD}$ dissertation process. Public records and university offices served as a source of needed demographic information. Nonrespondents were shown to be like respondents on all institutional measures-age, rank, years at the university, percent of time spent on research, undergraduate, master, and doctoral level teaching load, number of university leaves, number of research grants, and 
Table I. Average Percent of Time Spent on Dissertation Work

\begin{tabular}{|c|c|c|c|c|c|c|c|}
\hline \multirow[b]{3}{*}{ Function } & \multicolumn{7}{|c|}{ Departments } \\
\hline & \multicolumn{2}{|c|}{ Humanities } & \multicolumn{2}{|c|}{ Natural Sciences } & \multicolumn{2}{|c|}{ Social Sciences } & \multirow{2}{*}{$\begin{array}{l}\text { Totals } \\
(136)^{b}\end{array}$} \\
\hline & $\begin{array}{l}1^{a} \\
(46)^{b}\end{array}$ & $\begin{array}{c}2^{a} \\
(22)\end{array}$ & $\begin{array}{c}1 \\
(17)\end{array}$ & $\begin{array}{c}2 \\
(20)\end{array}$ & $\begin{array}{c}1 \\
(14)\end{array}$ & $\begin{array}{c}2 \\
(17)\end{array}$ & \\
\hline $\begin{array}{l}\text { Percent of } \\
\text { work effort }\end{array}$ & 7.8 & 14.3 & 12.8 & 17.6 & 12.8 & 9.6 & 11.5 \\
\hline
\end{tabular}

${ }^{a}$ Two different departments ( 1 and 2 ) were selected from each of the three disciplinary areas of the liberal arts. Anonymity guarantees preclude identifying the departments. However, the selection of departments follows Parsons \& Platt (1968).

${ }^{\mathrm{b}}$ Since the N's for this table are from the questionnaire, the table $\mathrm{N}$ is not 225 (the population). Subtracting for those on leave (approximately 5\%) and for a few incomplete responses, the total $\mathrm{N}$ falls below the $69 \%$ response rate in this instance.

number of dollars of research money available. Therefore $\mathrm{PhD}$ productivity figures can be used for the entire population.

\section{THE DATA}

The principal data needed for the analyses are displayed in the tables below. The estimated percent of faculty work effort spent on dissertations is given in Table 1 .

Table II gives $\mathrm{PhD}$ output per faculty member over a three-year period. It also shows the value the professor believes his department places on this dimension of the faculty work role.

The numbers of chairmanships and memberships faculty believe to be a reasonable load are given in Table III. Here high agreement obtains from department to department, unlike the data in Tables I and II.

To begin with, based on the percentage of work effort, hours worked per week, and $\mathrm{PhD}$ output, a straightforward calculation gives a number of hours faculty spend on dissertation work. Suppose the conservative faculty effort of 55 hours per week. (Studies at this university actually show 57 hours.) At $11.5 \%$ of effort, this is 6.3 hours per week. Suppose again a conservative estimate of 40 weeks per year, the 9-10 month academic year. (Actually faculty work the year around, especially with doctoral students.) The result is approximately 250 hours a year. (The three years for completion is cancelled by the supposition that three committees are being chaired at one time.)

This is no inconsequential number of hours. In addition, since equivalency of dissertation effort to other work roles-especially to teaching-are sought, it 


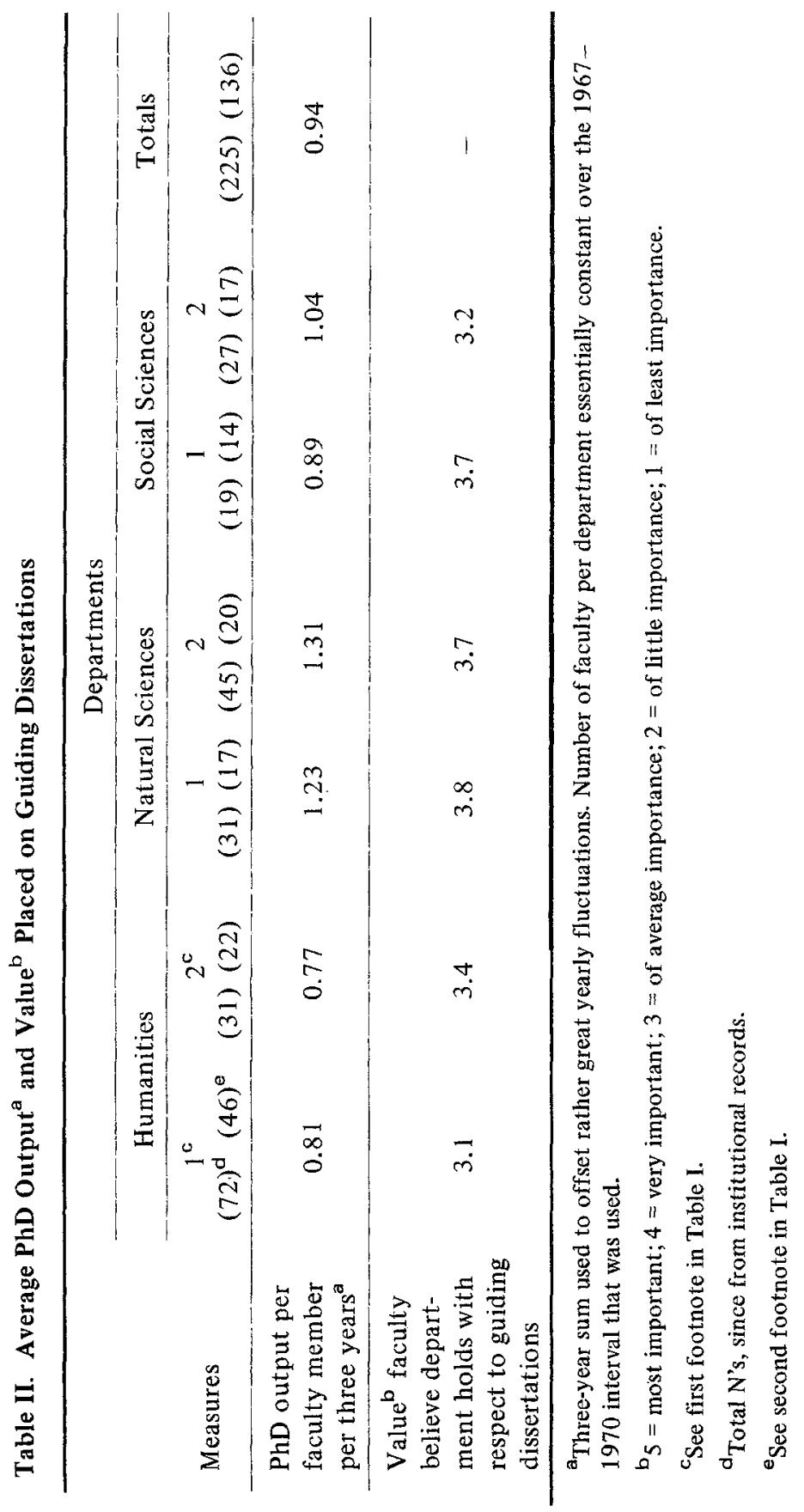


Table III. Faculty Opinion on Appropriate Dissertation Workload

\begin{tabular}{|c|c|c|c|c|c|c|c|}
\hline \multirow[b]{3}{*}{ Function } & \multicolumn{7}{|c|}{ Departments } \\
\hline & \multicolumn{2}{|c|}{ Humanities } & \multicolumn{2}{|c|}{ Natural Sciences } & \multicolumn{2}{|c|}{ Social Sciences } & \multirow{2}{*}{$\begin{array}{l}\text { Means } \\
(136)^{\mathrm{a}}\end{array}$} \\
\hline & $\begin{array}{c}1^{a} \\
(46)^{a}\end{array}$ & $\begin{array}{c}2^{a} \\
(22)\end{array}$ & $\begin{array}{c}1 \\
(17) \\
\end{array}$ & $\begin{array}{c}2 \\
(20) \\
\end{array}$ & $\begin{array}{c}1 \\
(14) \\
\end{array}$ & $\begin{array}{c}2 \\
(17) \\
\end{array}$ & \\
\hline $\begin{array}{l}\text { Chairman- } \\
\text { ships at one } \\
\text { time }\end{array}$ & 1.8 & 3.4 & 3.1 & 2.2 & 3.1 & 2.9 & 2.9 \\
\hline $\begin{array}{l}\text { Memberships } \\
\text { at one } \\
\text { time }\end{array}$ & 4.3 & 5.6 & 5.3 & 4.2 & 5.9 & 4.8 & 4.8 \\
\hline
\end{tabular}

${ }^{\text {a }}$ See the footnotes in Table I.

is imperative to demonstrate the reliability of the hours and of the work effort.

Several considerations lead to the conclusion that the professor's estimate of the percentage of his time is a dependable number, if anything, on the conservative side. First of all, the studies cited earlier (Stecklein, 1961; French et al., 1965) demonstrated that faculty are accurate estimators of the percentage of time they give to the different roles and functions they perform.

Second, and as additional corroboration, a social science department within the university (but not one of the two in this study) has successfully used a workload formula for their staff for over 10 years. This formula partitions faculty activities into major areas and to specific functions within each category. It uses a point system, with fractional units as small as 1/8. A full workload adds up to 12 units. For example, regular teaching receives one unit per credit taught. (Laboratory work, seminars, special lectures, and the like receive different degrees of credit.)

Data from the university's Office of Institutional Research shows this faculty to give slightly over $50 \%$ of its effort to regular course teaching. This selfreported faculty percentage agrees almost perfectly with other (independent) institutional data showing the faculty in this study to teach (on the average) 6.1 semester hours/term (Trowbridge, 1971, p. 54).

Third, the reported doctoral committee chairmanships and memberships are in the right proportion, 3 to 5 (see Table III). That is, a typical committee is four members, the chairman and at least one, but not more than two others, from within the department. The number of memberships are more than chairmanships but less than twice as frequent, on the average, as must be the case.

Furthermore, on this department's workload formula just cited, $1 / 2$ unit is 
given to each chairmanship, $1 / 8$ unit to each doctoral committee membership. At this rate, $2-1 / 8(3 \times 1 / 2+5 \times 1 / 8)$ of 12 units, or about $18 \%$ of a workload, falls within the self-reported estimates. The 3 and 5 committee figures are a "could." That is, faculty responded to what they might increase their load to include. Thus the $18 \%$ is probably a fraction high. Again, the $11.5 \%$ seems a highly reliable and accurate figure, and not an overestimate. It will be used from here on.

Lastly, because of its absolute magnitude, $11.5 \%$ is an interesting number. It is not so large that either faculty or administrators are attracted by its dominance. Nor is it so small as to be invisible, to escape detection. Variations about this means have implications, as seen below.

\section{RESULTS}

Other data from the study also have consequences and affect implications. (See Trowbridge (1971) for an extended presentation.) The relevant findings are reported.

\section{Individual Factors}

First of all, no faculty member had chaired a completed dissertation until he had been on the staff for more than four years. Second, one-third of those who had been at the university more than four years had not chaired a completed $\mathrm{PhD}$ disseration. Many had been on the staff more than 10 years. What this means is that about $50 \%$ of the faculty produced all of the graduated PhD's. Both these groups, however, nonproducers as well as producers, report they are engaged in working on dissertation committees with doctoral students.

Third, great variations exist within this productive group. Some faculty are producing PhD's at a rate 50 times more than others, from six per year to one every nine years. Individual output varies with percentage of workload given to this activity, but not in the same proportion. Those who are prodcing twice as many $\mathrm{PhD}$ 's are giving less than twice as many hours, assuming equal total hours per week.

Fourth, some characteristics of high faculty $\mathrm{PhD}$ producers differ significantly from low producers. However, many often supposed features failed to distinguish the high from low producer. For example, the high producer did not spend more time in research or have more research funds. He did, however, have a larger number of grants. Age and status (rank) were not related to output. The high producer was not judged by students to be a better teacher, but he did spend more time in social and informal contacts with graduate students. Interestingly, and most important, the high producer turned down more requests 
to chair committees than did the low producer. This difference was statistically significant $(\mathrm{p}<0.05)$.

\section{Institutional Factors}

Tables I and II have shown the variation in percentage of time allocated to $\mathrm{PhD}$ workload, the variation in output-the highest being $60 \%$ greater than the lowest-and the difference between departments on the value accorded this activity. (Yet there is no significant difference between faculty in the departments with respect to what they believe they can handle, an interesting paradox.) An inspection of the data reveals that time, output, and normative value go together. Those departments which attribute a high value to graduating PhD's produce more graduates and spend more time at it.

\section{CONCLUSIONS AND IMPLICATIONS}

\section{Within the University}

To begin with, a cost equivalent can be calculated for the first time. A faculty output of one PhD per year is approximately one-third of a workload. From the data of these six departments, graduating a $\mathrm{PhD}$ requires more effort than teaching one regular three hour course during a term. Since there is a price value on the credit hour, now there is a cost equivalency for $\mathrm{PhD}$ output.

A word of caution, however. The measure has to be PhD output, not effort. As was seen, nonproducers are also giving effort, but are not graduating candidates. Universities can provide data on the number of students matriculated into doctoral programs and the average time lapse from $\mathrm{BA}$ to $\mathrm{PhD}$ for those who successfully complete. Only rarely can they provide data on how many students are actually "in process," especially at the dissertation stage. It is only the number who graduate that can serve both as a measure of an individual professor's productivity and of institutional productivity.

Some difficulties will arise in assessing the load of an untried new faculty member. However, faculty can quite accurately predict their individual $\mathrm{PhD}$ output for the next 12 months. Planning can be conducted.

Within this restriction, $\mathrm{PhD}$ output can just as readily be the quantum of productivity as can the credit hour. Furthermore, since costs (salaries, support, etc.) are readily available, doctoral costs are now directly calculable.

A second major conclusion is the very profound fact that there are $\mathrm{PhD}$ producers and $\mathrm{PhD}$ nonproducers on the faculty. The differences are enormous, even when confined to those who are producers, differences which presumably would be even more accentuated if the most productive accepted every student request to become a sponsor.

The implications of this extensive variation are large. If the educational unit 
places a high value on $\mathrm{PhD}$ output, then administrators must recognize differential faculty workload. As matters now stand, most often the $\mathrm{PhD}$ chairmanship role is considered an unrecognized overload, an "extra" above and beyond the regular full compliment of teaching, research, and service. It comprises $11.5 \%$ of a professor's effort, on the average, and considerably more (about $20 \%$ ) for the highest producers. To ignore effort given to this work activity is to be grossly unfair to the individual faculty member who produces PhD's.

Third, an important implication is that department chairmen and deans need. to exercise better personnel management. The possibilities of attempting to distribute $\mathrm{PhD}$ workload more evenly over an entire faculty versus instituting differential faculty assignments should be carefully explored. The common practice of equalizing credit hours of teaching for all faculty (and time expected to be given to research and service) flaunts clearly demonstrated individual faculty differences.

Not known, but equally important, is the highly questionable assumption of a perpetual evenness in a professor's interests and effectiveness. He is given the same proportion of activities year after year. That he has no cycle in his career, no barren or fertile periods, say, with respect to research, flies in the face of almost all evidence of what happens psychologically and physiologically to a person from age 30 to 70 (see Blackburn (1972)).

If the number of staff is based on student credit hours, or some institutionwide student-faculty ratio, great injustices are practiced unless additional faculty per student are provided. Certainly an administrator wishing to increase his $\mathrm{PhD}$ output would selectively take on a faculty of high producers. Equally certainly he must recognize the work effort required to attain the goals set by society. A practice which recognizes individual faculty differences seems much more likely to achieve success than one which requires identical apportionments of faculty effort. In addition, the latter severely penalizes student options (and probably faculty desire, too). Obviously students are sensitive to faculty differences, for they turn to high producers. This is another reason it would be unwise to have administrators control chairmanships by allocation.

Finally, it is patently unfair to compare teaching loads at institutions and/or programs within an institution designated to be $\mathrm{PhD}$ producers with those that are not, or even to units which are only modestly in the business. Workload equivalency necessitates unequality in teaching typical course-credit-hours.

\section{External Relations}

While not nearly at the cost of training MD's, educating $\mathrm{PhD}$ 's does require a high fraction of faculty work effort. Just as a hospital has all MD's on its staff for supervising interns, so does a university require all doctoral committee members to have PhD's. Hence, at the studied university, and ones comparable to it, 
over $90 \%$ of their faculty have doctorates. The percentage contrasts with a national average for four-year colleges and universities of 53\% (Joughin, 1969) and of less than 10\% PhD's for junior and community colleges (Huther, 1972).

Hence a highly graduate-orientated university inevitably will have a higher proportion of its faculty at the upper ranks. More money will be allocated for these institutions than for others with fewer or no doctoral programs. ${ }^{3}$

Finally, the analysis has uncovered no evidence that faculty fall short with respect to accountability. They are hard at work, a number of hours exceeded by no other occupation (Gerstl, 1959; de Grazia, 1962). Like other human beings, they dislike being stereotyped, especially falsely. Faculty, too, believe they are unique, distinctive. They would like to have their special attributes duly recognized, not out of proportion to their worth, just fairly.

\section{REFERENCES}

Blackburn, R. T. (1972). "Tenure: Aspects of job security on the changing campus." Atlanta, Ga.: Southern Regional Education Board, Monograph no. 19, July, 1972.

Bunnell, K. (1960). "Faculty workload." Washington, D.C.: American Council on Education.

Carnegie Commission on Higher Education (1970). "Quality and equality." (Rev. Rec.), New York: McGraw-Hill.

Clark, M. J. (1968), Findlay college faculty distribution of work time. Unpublished report.

de Grazia, S. (1962). "Of Time, Work, and Leisure." New York: The Twentieth Century Fund.

French, J. R. P., Jr., Tupper, C. J., and Mueller, E. F. (1965). "Workload of University Professors." Ann Arbor, Mich.: Institute for Social Research, The University of Michigan.

\footnotetext{
${ }^{3}$ The argument is not advanced that professors at doctoral producing universities deserve more money because they are at doctoral producing universities. In any economic analysis of income vesus investment, faculty at doctoral universities fair the worst of all. The inequality is clearly seen when it can be shown that faculty at community colleges in this same state have an average salary which is $93 \%$ of the university in question. The community college faculty's Masters Degree took 3 to 7 years less to earn. Their cost of education is greatly less and their period for income greatly more. Community college faculty earn more per investment than teachers in schools on either side of them. This is not to argue (at least here) that university salaries should be higher. All it says is that faculty at doctoral universities did not choose to work there in order to get rich. They selected this particular career for nonmonetary reasons. Also, it is not fair to imply that those teaching at community colleges did so to become rich. They probably had other reasons, too. In fact, it really is absurd to entertain the notion of anyone, ever, anywhere, selecting an academic career because he or she wanted to acquire wealth.

Again, it is essential to keep firmly in mind that better and worse are in no ways an issue. Society's needs are for different kinds of human capital, for different kinds of expertise. Some simply are more expensive to train than are others.
} 
Gerstl, J. E. (1959). Career commitment and style of life in three middle class occupations. Unpublished doctoral dissertation, University of Minnesota.

Guthrie, E. R. (1949). The evaluation of teaching. Educational Record, 30:109-115.

Hansen, B. L. \& Sandler, S. (1967). "Report on the Study of Faculty Activities at the University of Toronto." Council of Ontario Universities, OIR, 1967, 9.

Huther, J. W. (1972). Small market for PhD's: The public two year college. American Association of University Professors Bulletin, 58:17-20.

Joughin, L. (1969). "Academic Freedom and Tenure: A Handbook of the American Association of University Professors." Madison: University of Wisconsin Press.

Keene, T. W. (1971). Selected characteristics of faculty workload. Presented at the American Association of Higher Education. Chicago, March, 1971.

Kilpatrick, E. G., Jr. (1969). Junior college faculty load. Unpublished doctoral dissertation, University of California, Los Angeles.

Koose, L. V. (1919). The adjustment of the teaching load in a university. Bureau of Education Bulletin, 15, Washington, D.C.

McElhaney, J. H. (1959). Attitudes of selected professors at Ohio State University regarding their workloads. Unpublished doctoral dissertation, Ohio State University.

Parsons, T., and Platt, G. (1968). "The American Academic Profession: A Pilot Study." National Science Foundation Grant GS 513, March, 1968.

Reeves, F. W., and Russell, J. D. (1929). "Instructional Loads." College Organization and Administration. Indianapolis, Ind.: Board of Education, Disciples of Chirst, pp. 165-182.

Richardson, H. D. (1967). Faculty Workload study and analysis. College and University, 43:108-114.

Russell, J. D. (1946). "Service Loads of Faculty Members. Problems of Faculty Personnel." Chicago, Ill.: University of Chicago Press, pp. 75-91.

Stecklein, J. E. (1961). "How to Measure Faculty Workload." Washington, D.C.: The American Council on Education.

Trowbridge, K. W. (1971). A study of faculty $\mathrm{PhD}$ productivity. Unpublished doctoral dissertation, University of Michigan, Ann Arbor.

United States Census of Population (1960). "Occupational Characteristics," U.S. Government Printing Office.

University of Michigan (1970). "Faculty Workload Study." Unpublished Data, Office of Institutional Research, Fall, 1970.

University of Minnesota (1970). Teachers work 57 hours. The Chronicle of Higher Education, March.

Western Interstate Commission for Higher Education (1961). "Studies of College Faculty." Boulder, Colorado: WICHE. 